\title{
KONCEPCJA NIEŚMIERTELNOŚCI CZLOWIEKA W ARGUMENTACJI REZUREKCYJNEJ METODEGO Z OLIMPU
}

Oczekiwanie rychłej paruzji to jedna z najbardziej charakterystycznych cech duchowości pierwszych pokoleń chrześcijan. Zagadnienia eschatyczne nie były głoszonymi teoretycznie prawdami, ale zbawiennym przesłaniem kształtującym styl życia. Centrum chrześcijańskiego kerygmatu stanowiła prawda o zmartwychwstaniu Jezusa Chrystusa. Niosła ona nadzieję na uczestnictwo wszystkich wiernych w Jego zwycięstwie nad grzechem i śmiercią, to jest na ostateczne zbawienie i wieczną szczęśliwość. Można wręcz postawić tezę, że eschatologia wczesnochrześcijańska żywiła się wiarą w zmartwychwstanie. $Z$ upływem lat ta wiara wymagała coraz bardziej szczegółowych uzasadnień, zwłaszcza w kwestiach antropologicznych. Człowiek, szczególnie w aspekcie jego cielesności, był przecież przedmiotem zainteresowania nie tylko teologii, ale również systemów filozoficznych i medycyny. Nie przez przypadek zatem $\mathrm{w}$ pierwszych trzech wiekach powstało wiele traktatów poświęconych zagadnieniu zmartwychwstania ${ }^{1}$. Jednym z nich jest dzieło Metodego z Olimpu.

Przedmiotem niniejszego artykułu jest próba zidentyfikowania założeń i zdefiniowania koncepcji antropologicznych leżących u podstaw poglądów biskupa Olimpu wyrażonych w dialogu $O$ zmartwychwstaniu. Szczególne miejsce zajmie analiza zagadnienia pierwotnego statusu człowieka, a więc metodiańska interpretacja biblijnych opisów dotyczących stworzenia. Porównanie z poglądami niektórych wcześniejszych autorów pozwoli określić nie tylko ideowe zależności, ale ponadto przekonać się w jaki sposób cel dzieła i kontekst epoki wpływa na przyjęcie określonych rozwiązań doktrynalnych i filozoficznych. Zostanie wreszcie podjęta próba wyjaśnienia relacji pomiędzy obroną tradycyjnego rozumienia dogmatu o zmartwychwstaniu ciała

* Dr Mirosław Mejzner SAC - adiunkt w Katedrze Teologii Patrystycznej w Instytucie Teologii Systematycznej na Wydziale Teologicznym Uniwersytetu Kard. Stefana Wyszyńskiego w Warszawie; e-mail: m.mejzner@uksw.edu.pl.

${ }^{1}$ Należy wymienić przede wszystkim dzieła Pseudo-Justyna, Atenagorasa, Tertuliana, Ireneusza, Orygenesa. Pogłębione studium myśli rezurekcyjnej, zob. M. Szram, Ciało zmartwychwstałe w myśli patrystycznej przełomu II i III wieku, Lublin 2010. 
a szczególną wizją protologiczną, jaką była koncepcja istotowej nieśmiertelności człowieka.

1. Polemiczny kontekst dyskusji o zmartwychwstaniu. Dzieło Metodego $O$ zmartwychwstaniu ${ }^{2}$ jest w pewnym sensie szczególne. Napisane pod koniec jego życia, najprawdopodobniej ok. 310 r., stanowiło pierwszą tak gruntowną reakcję na rezurekcyjne poglądy Orygenesa, który na bazie platońskiej antropologii ${ }^{3}$ usiłował wyjaśnić tożsamość ciała ziemskiego ze zmartwychwstałym przy pomocy dwuznacznego i abstrakcyjnego pojęcia عîঠo $\sigma \omega \mu \alpha \tau \iota \kappa o ́ v$. Biskup Olimpu uważał, że takie wyjaśnienie jest nie do pogodzenia z chrześcijańskim dogmatem wiary, gdyż kwestionuje materialność ludzkiego ciała. Jego traktat, ujęty w formę dialogu, już w starożytności był bardzo ceniony i wielokrotnie przywoływany ${ }^{4}$. Autor podjął w nim bardzo dojrzałą próbę uzasadnienia w sposób kompleksowy tradycyjnego rozumienia dogmatu o zmartwychwstaniu. Starał się przy tym nie tylko wykazać niedorzeczność zarzutów płynących ze środowisk platońskich i gnostyckich oraz wypunktować niedoskonałości koncepcji عî̉os $\sigma \omega \mu \alpha \tau \imath \kappa o ́ v$, ale dowieść ponadto, że wiara $\mathrm{w}$ zmartwychwstanie ciała jest zgodna $\mathrm{z}$ rozumem i naukowym rozumieniem człowieka i świata.

Spór Metodego z Orygenesem pozwala zrozumieć pewne tendencje eschatologiczne u schyłku III w. Główna polemika dotyczyła nie tyle kwestii teologicznych, co antropologicznych. Szczególnego znaczenia nabrała egzegeza tekstów biblijnej protologii. W nich poszczególni autorzy wczesnochrześcijańscy szukali źródeł i umocowania dla swoich tez. Nie inaczej postępował Metody. Jego najpiękniejsze i najbardziej wartościowe refleksje o zmartwychwstaniu należą do dziedziny antropologii teologicznej ${ }^{5}$. Autor był słusznie przekonany, że obrona tradycyjnego rozumienia rezurekcyjnego dogmatu nie jest możliwa bez solidnego umocowania na fundamencie ontycznej wartości ciała. Dlatego z całą mocą podkreślał, że przynależy ono istotowo do natury

${ }^{2}$ Wydanie krytyczne dzieł Metodego z Olimpu: G.N. Bonwetsch, GCS 27, Leipzig 1917 (De resurrectione, s. 219-424). Passusy zachowane jedynie w przekładzie starocerkiewnosłowiańskim (manuskrypt Q.I. 265 przechowywany w Rosyjskiej Bibliotece Narodowej w Petersburgu) zostały przetłumaczone w GCS 27 na język niemiecki; włoskiego przekładu dzieła dokonali Mirosław Mejzner i Benedetta Zorzi: Metodio di Olimpo, La risurrezione. Introduzione e traduzione di M. Mejzner SAC (parte paleoslava) e M.B. Zorzi OSB (parte greca), Collana di Testi Patristici 216, Roma 2010).

${ }^{3}$ Platon (Alcibiades I 130C) definiował człowieka jako duszę posługującą się ciałem.

${ }^{4}$ Hieronim (De viris illustribus 83) określił De resurrectione Metodego mianem „opus egregium"; Epifaniusz przytoczył znaczną część dialogu Metodego w Panarion 64, przyczyniając się $\mathrm{w}$ ten sposób do zachowania go w greckiej wersji oryginalnej.

${ }^{5}$ Jedną z zasadniczych cech myśli Metodego jest koncepcja doskonałości człowieka coram Deo, por. K. Bracht, Vollkommenheit und Vollendung. Zur Anthropologie des Methodius von Olympus, Studien und Texte zu Antike und Christentum 2, Tübingen 1999, 2. Pogłębione studium eschatologii Metodego, por. M. Mejzner, L'escatologia di Metodio di Olimpo, SEA 124, Roma 2011. 
ludzkiej i jest konieczne do pełni człowieczeństwa.

Wzmagająca się polemika wokół zmartwychwstaniu wymagała spójnej i coraz bardziej precyzyjnej argumentacji. Jednym z jej elementów było określenie pierwotnego statusu człowieka. W kontekście tych właśnie rezurekcyjnych sporów, Metody wprowadził ideę, którą można nazwać „istotową (początkową, principaliter) nieśmiertelnością człowieka”. Na tle poglądów antropologicznych ówczesnej tradycji chrześcijańskiej wydaje się być ona koncepcją nowatorską.

2. Protologiczne założenia tzw. tradycji azjatyckiej. Jednym z ważnych aksjomatów egzegetycznych u przedstawicieli tradycji azjatyckiej ${ }^{6}$ we wczesnym chrześcijaństwie było komplementarne odczytywanie dwóch opisów stworzenia człowieka z Księgi Rodzaju. Dzięki takiej interpretacji utrzymywali oni, że człowiek - stworzony na obraz i podobieństwo Boże - został od poczattu ukonstytuowany w swej strukturze duchowo-cielesnej. Autorzy ci zachowywali jednak daleko posuniętą ostrożność w określeniu czy Adam otrzymał udział w nieśmiertelności czy też miał ją dopiero uzyskać. Biorąc pod uwagę powszechny fakt śmierci, którą uznawali za konsekwencję grzechu, twierdzili zazwyczaj, że stan pierwszego człowieka nie był całkowicie ustalony, ale że został on usytuowany pomiędzy śmiertelnością a nieśmiertelnościa, skazitelnością i nieskazitelnością. Ta koncepcja medietas została wyrażona mniej lub bardziej precyzyjnie w kilku pismach wczesnochrześcijańskich.

Najbardziej wyrazisty przykład jest zawarty w dziele Teofila Do Autolika:

„Lecz powie nam ktoś: «Człowiek otrzymał naturę śmiertelną?» Wcale nie! «A może nieśmiertelną?» Tego również nie twierdzimy. Zapyta więc ktoś: «Więc ani jedną ani drugą?» Tego również nie twierdzimy. Człowiek więc nie został stworzony ani śmiertelnym, ani nieśmiertelnym z natury $[\ldots]$, ale zdolnym do jednego i do drugiego, aby jeśli będzie skłaniał się ku nieśmiertelności, zachowując przykazanie Boga, jako nagrodę otrzymał od Niego nieśmiertelność i stał się jakby Bogiem, jeśli natomiast zwróci się ku czynom śmierci, nie słuchając Boga, wtedy sam stanie się sprawcą swojej śmierci. Bóg bowiem stworzył człowieka wolnym i odpowiedzialnym"7.

Teofil wplótł koncepcję medietas w rozważania o wolności woli i rzutującej na wieczność odpowiedzialności za czyny. Według niego, zarówno Bóg, jak i człowiek są aktywnymi podmiotami egzystencjalnej dynamiki. Bóg

${ }^{6}$ Schematycznego podziału na dwie tradycje kulturowe wczesnego chrześcijaństwa: azjatycką i aleksandryjską, dokonał Manlio Simonetti (Modelli culturali nella cristianità orientale del II-III secolo, w: De Tertullien aux Mozarabes, 1. Antiquité tardive et Christianisme ancien $\left(I I I^{e}-V I^{e}\right.$ siècles). Mélanges offerts à Jacques Fontane, Paris 1992, 381-392). Metody z Olimpu, zaliczony przez niego do autorów azjatyckich, nie mieści się w pełni w ramach takiej klasyfikacji.

${ }^{7}$ Teophilus, Ad Autolycum II 27, ed. G. Bardy, SCh 20, Paris 1948, 164, thum. L. Misiarczyk, w: Pierwsi apologeci greccy, BOK 24, Kraków 2004, 424-425. 
nagradza wieczną szczęśliwością za wierność jego przykazaniu, natomiast to człowiek sam skazuje się na śmierć przez grzeszne nieposłuszeństwo.

$\mathrm{W}$ podobnym tonie, choć $\mathrm{w}$ innym kontekście, wypowiadał się również Ireneusz z Lyonu. Zgodnie ze swymi założeniami doktrynalnymi, starał się on bardzo mocno dowartościować ciało, wskazując je jako podstawowy podmiot rywalizacji życia i śmierci:

„Ciało jest podatne zarówno na zniszczenie, jak i niezniszczalność, otwarte na życie i na śmierć. Te rzeczywistości wzajemnie się wykluczają, tak że obydwie nie mogą trwać w tym samym podmiocie, ale jedna wypiera drugą, w ten sposób, że gdy trwa jedna to nie ma tej drugiej. Jeśli więc śmierć, która zapanowała nad człowiekiem, wyrugowała z niego życie i ukazała go śmiertelnym, to o wiele bardziej życie, gdy zapanuje w człowieku, wyruguje z niego śmierć i żyjącego człowieka przywróci Bogu"».

Podstawą koncepcji medietas, rozpowszechnionej wśród autorów chrześcijańskich II w., była egzegeza biblijnych opisów stworzenia. Starali się oni wyjaśnić przyczynę śmierci, a jednocześnie dokonać apologii Boga-Stwórcy przy pomocy kategorii wolności człowieka. Podkreślali więc, że dobry jest Bóg, który powołał człowieka do życia i nieśmiertelności. To sam człowiek, zwiedziony wprawdzie przez diabła, poddał się mocy śmierci w wyniku nieposłuszeństwa i złego wyboru.

Koncepcja medietas była Metodemu dobrze znana i w pełni przez niego podzielana. Szczególnie wyraźna jest w jego wczesnym dziele Symposium czyli Uczta (dziesięciu dziewic):

„Człowiek natomiast, jako byt pośredni, sam z siebie nie jest ani sprawiedliwością, ani niesprawiedliwością, lecz znalazłszy się pomiędzy nieskazitelnością i skazitelnością waha się i skłania ku jednej albo ku drugiej i, jak się zdaje, przybiera naturę tego, co nad nim zapanowało: gdy skłoni się ku skazitelności, staje się skazitelny i śmiertelny, a kiedy wybierze nieskazitelność, jest nieskazitelny i nieśmiertelny. Umieszczony bowiem w środku między «drzewem życia» a «drzewem wiadomości dobrego i złego» przekształca się w postać związaną z drzewem, z którego owoce spożywał [...]. Człowiek zatem nie jest ani dysharmonią i nierównowagą, ani równowagą i harmonią; kiedy wszedł w dysharmonię, to znaczy występek i grzech, stał się nieharmonijny i nieokrzesany; kiedy zaś przyjął harmonię, czyli sprawiedliwość, stał się harmonijnym i przyzwoitym instrumentem, a Pan, który jest Niezniszczalnością,

${ }^{8}$ Irenaeus, Adversus haereses V 12, 1, ed. ed. A. Rousseau - L. Doutreleau - C. Mercier, SCh 153, Paris 1969, 140-142: „Quemadmodum enim corruptelae capax est caro, sic et incorruptelae, et quemadmodum mortis, sic et vitae. Haec autem invicem cedunt et utraque non permanent in idipsum, sed expellitur alterum ab altero et praesente altero interit alterum. Si igitur mors possidens hominem expulit ab eo vitam et mortuum ostendit, multo magis vita possidens hominem expellet mortem et viventem hominem restituet Deo", thum. własne. 
zwycięzcą śmierci, w melodyjnej pieśni głosi ciału zmartwychwstanie i nie pozwala, by zostało ono ponownie owładnięte przez zagładę" .

Podobne sformułowania możemy znaleźć także w jednym z passusów De resurrectione. W rozważaniach o pierwotnym statusie ciała, inspirowanych zapewne myślą Ireneusza z Lyonu, Metody tak napisał:

„Ciało zostało ukształtowane w stanie pomiędzy nieskazitelnością i skazitelnością. Nie będąc ani skazitelnością, ani nieskazitelnością zostało zwyciężone przez skazitelność z powodu hedonistycznego impulsu, choć było dziełem i własnością nieskazitelności. Dlatego właśnie stało się skazitelne i zniszczało w prochu ziemi.

Po tym jak [ciało] zostało zwyciężone przez skazitelność i za karę (na wychowanie) wydane śmierci, Bóg nie pozostawił go we władaniu skazitelności, jak ofiarę dla zwycięzcy, lecz po swoim zwycięstwie nad śmiercią poprzez zmartwychwstanie przywrócił ją nieskazitelności, tak, aby skazitelność nie zawłaszczyła nieskazitelności, lecz aby nieskazitelność posiadła to, co było skazitelne"10.

Główna myśl zawarta w obydwu cytatach jest bez wątpienia bardzo podobna, a jest nią koncepcja medietas. Jednak przy bardziej precyzyjnym porównaniu można zaobserwować znaczące różnice i wymowne przesunięcia treściowych akcentów. Pośród nich należy zwrócić uwagę na kilka najważniejszych doprecyzowań, które Metody zawarł w tym drugim passusie. Po pierwsze, jako obszar walki między nieskazitelnością a skazitelnością, wskazał „ciało”, a nie ogólnie ,człowieka”, jak to uczynił w Symposium. To antropologiczne uszczegółowienie było pochodną jego koncepcji zmartwychwstania, które bezpośrednio miałoby obejmować jedynie element cielesny, a człowieka tylko pośrednio, w znaczeniu, że nieśmiertelna dusza miałaby się złączyć z ożywionym i przemienionym ciałem. Po drugie, po wyrażeniach stwierdzających usytuowanie ciała pomiędzy dwoma przeciwstawnymi biegunami ontologicznymi, Metody skrupulatnie zaznaczył, że ciało było „dziełem i własnością nieskazitelności" (czego brak w Symposium III 7). Poprzez to wymowne przeciągnięcie statusu ciała ku pierwotnej doskonałości, spowodował zachwianie

\footnotetext{
${ }^{9}$ Methodius, Symposium III 7, ed. H.A. Musurillo - V.H. Debidour, SCh 95, Paris 1963, 104, tłum. S. Kalinkowski, w: Pierwsze pisma greckie o dziewictwie, ŹM 16, Tyniec - Kraków 1997, 154-155.

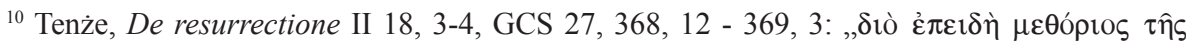

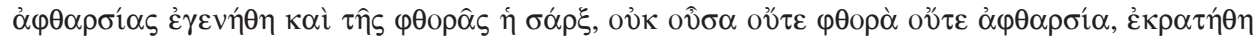

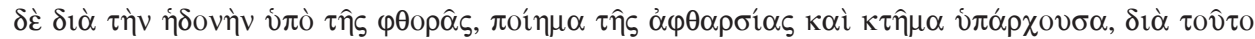

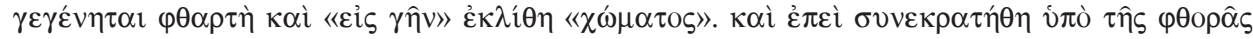

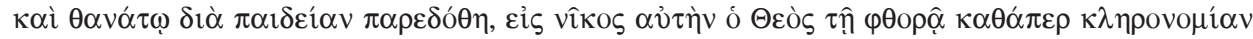

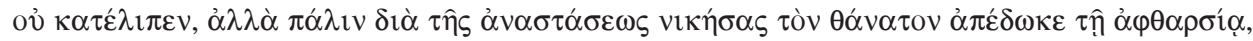

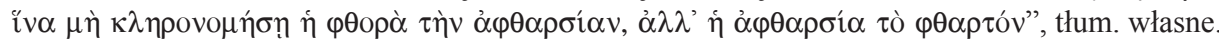


pewnej zrównoważonej nieokreśloności, zawartej w koncepcji medietas. Po trzecie stwierdził, że zmartwychwstanie przywróci ciało nieskazitelności, sugerując w ten sposób, że ta kondycja nie będzie zupełnie nowa dla człowieka, ale że pierwotnie była jego faktycznym stanem naturalnym, choć czasowo zakłóconym przez grzech. Warto ponadto dodać, że zniszczalność nie została powiązana w De resurrectione z ,drzewem poznania dobra i zła”, a więc rzeczywistością rajska, stworzoną przez Boga. Za podstawowy symbol śmiertelności zostały uznane „odzienia ze skór”, którymi Bóg przyoblekł ludzi po grzechu. Dzięki takiej kompozycji, mającej na celu polemikę z Orygenesową egzegezą Rdz 3, 21, Metody również złamał pewien paralelizm i równowagę koncepcji medietas. Wykorzystał bowiem pewien dystans, i to zarówno jakościowy, jak i chronologiczny, pomiędzy „drzewem życia” a „odzieniami ze skór". Chciał przez to wskazać, że życie należy do pierwotnego planu Boga, natomiast śmiertelność jest środkiem pokutnym, ustanowionym później, aby wyrwać człowieka ze skażenia grzechem i przyprowadzić go z powrotem do nieskazitelności w zmartwychwstaniu.

Wszystkie te znaczące modyfikacje pozwalają na przypisanie Metodemu poglądu, który można nazwać ,istotową lub początkową (principaliter) nieśmiertelnością człowieka". Od razu należy jednak zaznaczyć, że nie jest to koncepcja istotowo różna od tej klasycznej medietas, ale stanowi raczej jej odmianę, skonstruowaną w celu wzmocnienia antropologicznych fundamentów dogmatu o zmartwychwstaniu ciała. Istotnie, pierwsze zwiastuny tej koncepcji można znaleźć już w Symposium, gdzie mowa jest np. o ,pierwotnej niezniszczalności namiotu" ${ }^{11}$ czyli ciała oraz o człowieku, który został poddany śmierci, chociaż „nie był śmiertelny i zniszczalny" 12 . Jednak pełny wyraz idea nieśmiertelności principaliter uzyskała dopiero w dziele $O$ zmartwychwstaniu.

3. Przyczyny modyfikacji koncepcji medietas. Próba odejścia od bezpiecznego paralelizmu koncepcji medietas na rzecz dosyć ryzykownej i trudnej do wyjaśnienia koncepcji ,istotowej nieśmiertelności człowieka” rodzi zasadne pytania o przyczyny takiej myślowej ewolucji. Wydaje się, że było ich co najmniej kilka.

Oprócz zdecydowanie odmiennych celów obydwu dzieł Metodego, należy podkreślić fakt, że w obliczu krytyki chrześcijańskich dogmatów ze strony różnych szkół filozoficznych i gnostyckich, koniecznością było stosowanie coraz bardziej precyzyjnej i spójnej argumentacji. Podstawowym celem Metodego nie było już pogłębianie kwestii ascetycznych i duchowych związanych z dziewictwem, ale wykazanie doktrynalnej słuszności i zasadności zmartwychwstania ciała. W związku z tym wszelkie argumenty, które mogły dowartościować ontologiczny status ciała, w tym jego pierwotną nieśmiertelność,

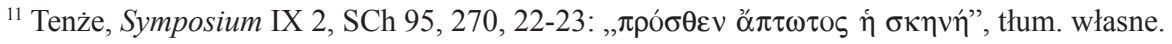

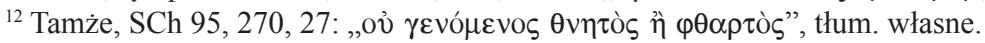


nabierały szczególnego znaczenia. Biskup Olimpu starał się wykazać, że status eschatyczny człowieka nie będzie jakąś zupełnie nową rzeczywistością, nie mającą żadnego związku z dziełem stworzenia, ale wręcz przeciwnie, że będzie on pełną realizacją pierwotnego planu nieomylnego Boga, który stworzył człowieka (z duszą i ciałem) dla nieśmiertelności.

Oprócz potrzeby coraz większej spójności argumentacyjnej i terminologicznej, wydaje się, że był jeszcze inny powód odejścia Metodego od koncepcji medietas w kierunku idei pierwotnej nieśmiertelności. Otóż, na horyzoncie chrześcijańskiej refleksji pojawiła się i szybko zyskiwała zwolenników konkurencyjna wizja opisująca powstanie człowieka i określająca jego pierwotny status. Chodzi mianowicie o aleksandryjską ideę dwu- czy nawet trzyetapowego stworzenia człowieka, tj. duszy nieśmiertelnej, potem jego eterycznego ciała, a w końcu ciała ziemskiego (do czego odnosiłyby się odpowiednio biblijne opisy Rdz 1, 26-27: człowiek na obraz i podobieństwo; Rdz 2, 7: człowiek ulepiony z prochu ziemi; i Rdz 3, 21: człowiek obleczony w ,odzienie ze skór"). Taka interpretacja biblijnej protologii oparta była na kluczowej idei preegzystencji dusz. Diametralnie odmienny punkt wyjścia prowadził w konsekwencji do podważenia sensowności tradycyjnej koncepcji medietas. Podszyta platonizmem aleksandryjska antropologia prowadziła też do określonych konsekwencji eschatologicznych. Jedną z nich było zakwestionowanie sensu zmartwychwstania ciała, co miało miejsce w niektórych środowiskach chrześcijańskich ${ }^{13}$.

Podważenie ontologicznego znaczenia ciała ziemskiego wywołało w dziele Metodego swoistą antyreakcję, polegającą na podkreśleniu jego pierwotnej nieśmiertelności, a przede wszystkim wykazaniu równoważności z duszą w definiowaniu człowieka. Biskup Olimpu nie polemizował z ideą nieśmiertelności duszy, przyjmując ją za pewnik ${ }^{14}$. Idea ta wywołała jednak wiele zmian w azjatyckiej antropologii i eschatologii. Podstawową konsekwencją uznania nieśmiertelności duszy było złączenie kwestii śmierci i zmartwychwstania jedynie z ciałem. Wczesne formuły mówiące o zmartwychwstaniu umarłych nabierały więc nieco innego znaczenia. Nie oczekiwano już, że pogrążony we śnie śmierci człowiek zostanie obudzony i przeniesiony do krainy życia,

${ }^{13}$ Wydaje się, że Pseudo-Justyn polemizował z platonizującymi chrześcijanami, którzy wierzyli w nieśmiertelność duszy, lecz odrzucali zmartwychwstanie ciała. Natomiast Justyn (Dialogus cum Tryphone Iudeo 80, 2) nazywa „niewiernymi i bezbożnymi heretykami” tych, którzy twierdzą, że „nie ma zmartwychwstania umarłych, ale że w chwili śmierci ich dusze idą natychmiast do nieba”.

${ }^{14}$ Zarówno platonicy i gnostycy, jak i Orygenes przyjmowali koncepcję nieśmiertelności duszy. Natomiast pierwsi przedstawiciele tzw. tradycji azjatyckiej pierwotnie nie podzielali jej w takiej formie, odmawiając duszy możliwości swobodnego życia po śmierci. Późniejsze uznanie nieśmiertelności duszy było, na poziomie filozoficznym, swoistą modyfikacją arystotelesowej definicji człowieka jako złożenia duszy i ciała, definicji, która umożliwiała rozwinięcie argumentacji za sensownością oczekiwania na zmartwychwstanie ciała. Por. Simonetti, Modelli culturali nella cristianità orientale del II-III secolo, s. 389-391. 
lecz że jego nieśmiertelna dusza połączy się ze wskrzeszonym i zaopatrzonym w nowe właściwości ciałem.

Metody zawsze ilekroć mówił o nieśmiertelności czy niezniszczalności człowieka, odnosił je do jego ucieleśnionej egzystencji. Uważał, podobnie zresztą jak Ireneusz, że sama dusza nie definiuje człowieka. Dlatego właśnie oczekiwanie na zmartwychwstanie ciała było kardynalnym elementem jego antropologii. Natomiast uznanie nieśmiertelności człowieka za jego naturalny i pierwotny stan, prowadziło do określonych konsekwencji eschatologicznych, zwłaszcza do wykazania konieczności zmartwychwstania, które urastało do rangi kluczowego momentu realizacji pierwotnego planu Boga.

4. Uzasadnienie koncepcji istotowej nieśmiertelności czlowieka. Fakt, że punktem wyjścia argumentacji Metodego była określona przez aksjomaty teologii azjatyckiej egzegeza tekstów biblijnych jest sprawą oczywistą. Zdumiewające jest natomiast, że do uzasadnienia nieśmiertelności ciała wykorzystał on pewne założenia filozofii platońskiej.

Biskup Olimpu często używał, zaczerpniętego od Ireneusza, wyrażenia, iż człowiek został uformowany „rękami Boga”. Dzięki takiej obrazowej kategorii chciał wykazać, że Adam został stworzony przez Boga bezpośrednio, niejako z osobistym zaangażowaniem, a nie ,jedynie” przez Słowo pełne mocy. Teza ta posłużyła mu do wyciągnięcia daleko idących wniosków, tych mianowicie, że każda istota stworzona w ten sposób jest nieśmiertelna, jako dzieło Nieśmiertelności.

,[Bóg] wiedział, że wszystko, co uformuje własnymi rękami będzie z konieczności nieśmiertelne, jako dzieło Nieśmiertelności. To, co nieśmiertelne jest nieśmiertelne dzięki Nieśmiertelności [...]. Na podstawie tego rozumowania można stwierdzić, że jaki jest ten, który tworzy, takie z konieczności jest dzieło wytworzone. Bóg jest Nieśmiertelnością i Życiem i Nieskazitelnością. Człowiek jest dziełem Boga. Wszystko co jest dziełem Nieśmiertelności jest nieśmiertelne. Człowiek zatem jest nieśmiertelny. $\mathrm{Z}$ tego powodu Bóg osobiście stworzył człowieka, a inne rodzaje istot żywych nakazał wytworzyć powietrzu, ziemi i wodzie"15.

Punktem wyjścia koncepcji Metodego jest tutaj biblijny opis stworzenia.

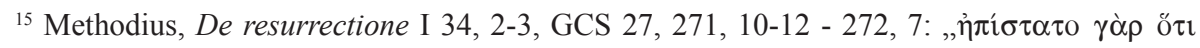

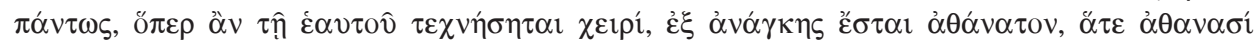

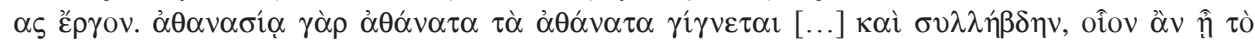

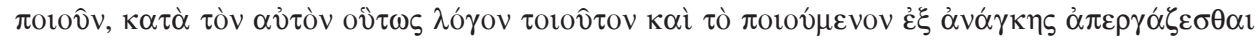

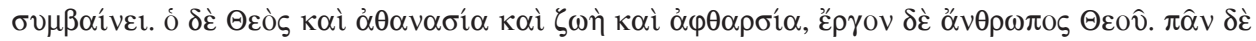

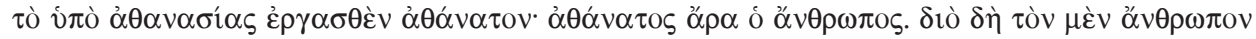

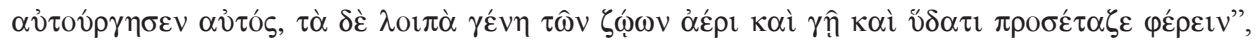
tłum. własne. 
Jednak ostateczny wniosek oparty jest na przesłankach filozofii platońskiej ${ }^{16}$. Biskup Olimpu przedstawia swoje rozumowanie w formie prostego sylogizmu: dzieło nieśmiertelności (tj. Boga) jest nieśmiertelne; człowiek jest dziełem Boga; zatem człowiek jest nieśmiertelny.

Ta zdecydowana i jednoznaczna afirmacja początkowej nieśmiertelności człowieka była wyraźną odpowiedzią na argumenty strony przeciwnej, wyrażane w dziele $O$ zmartwychwstaniu przez Aglaofona. Ta, najprawdopodobniej, fikcyjna postać uosabia poglądy chrześcijańskie o silnym zabarwieniu platońskim, czy wręcz poglądy platońskie podszyte chrześcijaństwem. Aglaofon jest zwolennikiem teorii preegzystencji dusz. Wcielona ludzka egzystencja ma - jego zdaniem - wtórny charakter. Uważa, że biblijne opisy stworzenia człowieka dotyczą rzeczywistości duchowych, zaś przyobleczenie ciałem nieśmiertelnych i preegzystujących dusz nastąpiło w momencie wygania ich z raju. Jego zdaniem ta „dekadencja” została w Rdz 3, 21 ukryta pod symbolicznym obrazem „odzienia ze skór”, którym zostali przyobleczeni pierwsi rodzice. Aglaofon określa więc ciało jako rzeczywistość wtórną, drugorzędną i czasową, a na dodatek obciążającą duszę. Punktem wyjścia i siłą jego argumentacji jest ogólnoludzkie doświadczenie śmierci. Analizując to doświadczenie wysuwa on dwa zasadnicze argumenty przeciwko poglądowi o istotowej nieśmiertelności człowieka $\mathrm{w}$ jego statusie istoty wcielonej.

Pierwszy z nich wynika z przypisania prerogatywie nieśmiertelności wartości absolutnej, wykluczającej wszelką zmienność:

„Jeżeli ta istota żyjąca była nieśmiertelna od początku, to w jaki sposób, waszym zdaniem, stała się śmiertelna, skoro to co nieśmiertelne musi z konieczności pozostawać niezmienne w swym bycie, bez przemiany w coś gorszego i mającego śmiertelną naturę? To istotnie niemożliwe, ponieważ nie byłaby już nieśmiertelna""17.

Rozumowanie Aglaofona można sprowadzić do prostego sylogizmu: byt nieśmiertelny jest niezmienny; pierwszy człowiek został poddany zmianie śmierci; a zatem pierwszy człowiek nie był nieśmiertelny. Aglaofon chciał w ten sposób wykazać niedorzeczność oczekiwania na zmartwychwstanie ciała, dowodząc, że nawet w przypadku pierwszego człowieka połączenie duszy i ciała miało charakter tymczasowy.

${ }^{16}$ Por. Plato, Gorgias 460B, ed. ed. E.R. Dodds, Oxford 1959, 88, thum. W. Witwicki, w: Platon, Dialogi, t. 1, Kęty 1999, 358: „A sprawiedliwy, chyba, postępuje sprawiedliwe?”; tenże, Timaeus 69C, ed. R.G. Bury, Cambridge 1981, 178, tłum. W. Witwicki, w: Platon, Dialogi, t. 2, Kęty 1999, 722: ,[bóg] istot boskich sam stał się wykonawcą, a powstanie śmiertelnych zlecił do wykonania tym, których sam zrodził".

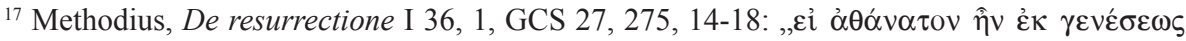

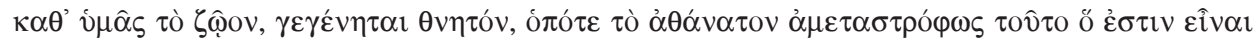

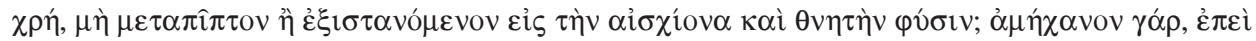

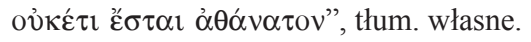


Drugi argument Aglaofona jest swoistą modyfikacją pierwszego. Heterodoks wskazał mianowicie na pożądliwość jako szczególny wyraz zmienności.

„Istoty spłodzone pożądają zjednoczenia (seksualnego) i pokarmu; posiadanie pożądliwości jest znakiem choroby, podczas gdy brak potrzeb i pożądań - zdrowia. Istoty spłodzone są chore, ponieważ pożądają, podczas gdy te niespłodzone nie są chore. To, co chore cierpi z powodu nadmiaru lub braku tego, co zostaje im dodane lub odjęte, a to, co cierpi już od momentu spłodzenia marnieje i ginie. Człowiek został spłodzony, dlatego nie może być ani niecierpiętliwy, ani nieśmiertelny"18.

Wspólnym mianownikiem argumentacji Aglaofona było założenie, że nieśmiertelność jest nierozerwalnie związana z niezmiennością i niecierpiętliwością. Metody z kolei, jasno rozróżniał te kategorie, co pozwalało mu podjąć polemikę z rozumowaniem swego adwersarza. Jego zadanie było jednak o tyle trudne, że - wobec oczywistości i powszechności doświadczenia śmier-

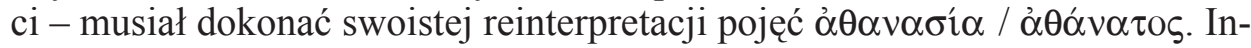
nymi słowy, musiał uzasadnić w jaki sposób można utrzymywać pierwotną nieśmiertelność człowieka, wobec faktu cielesnej śmierci Adama.

Prezentację argumentacji Metodego warto rozpocząć od analizy jego odpowiedzi na drugi zarzut Aglaofona.

„Jeżeli rzeczywiście wszystko co zostało stworzone czy spłodzone ginie, a możemy tak powiedzieć, bo przecież także i pierwsi rodzice nie byli spłodzeni, lecz stworzeni, to w takim wypadku oznacza, że również i aniołowie, i dusze gina, ponieważ tak aniołowie, jak i dusze zostali stworzeni: «czyni z duchów swoich aniołów» (Ps 104, 4)! A przecież ani aniołowie, ani dusze nie giną. Istotnie, są nieśmiertelni i niezniszczalni, tak jak chciał Ten, który ich stworzył. Dlatego też i człowiek jest nieśmiertelny!"19

Kluczem argumentacji Metodego jest tu analiza filologiczno-filozoficzna dwóch możliwych sposobów zaistnienia, wyrażonych dwoma czasownikami: 1) stworzenie czyli bezpośrednie pochodzenie od Boga ( $\left.\gamma^{\prime} \gamma \nu o \mu \alpha \imath\right)$ i 2)

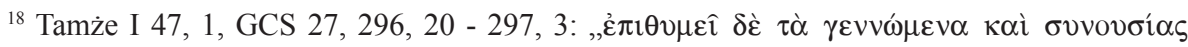

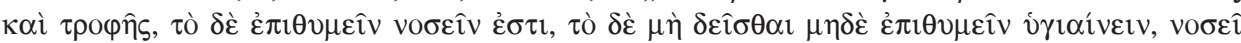

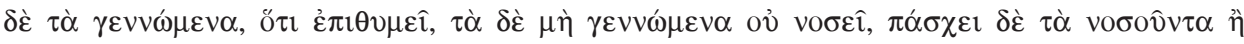

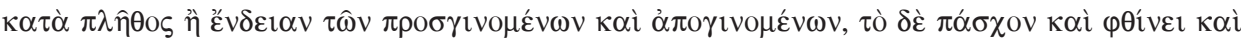

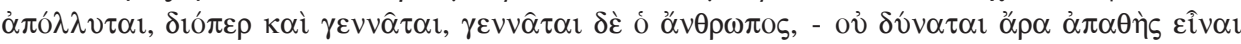

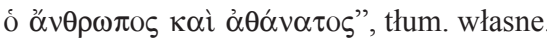

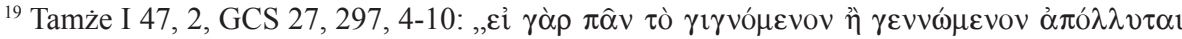
(

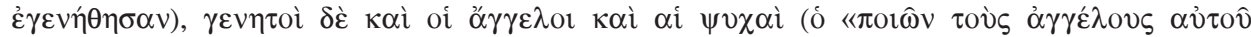

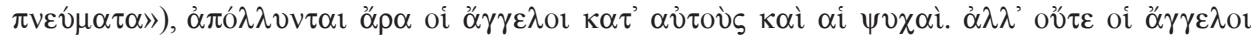

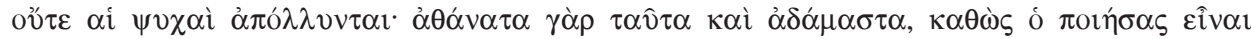

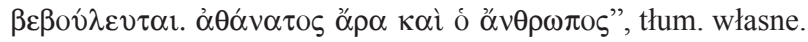


prokreacja fizyczna ( $\gamma \varepsilon v v o ́ \omega)$. Biskup Olimpu zauważył, że pierwsi rodzice nie powstali w wyniku ludzkiej prokreacji, lecz zostali stworzeni bezpośrednio przez Boga, to znaczy powołani do istnienia tak, jak aniołowie czy dusze. Wychodząc $\mathrm{z}$ takiego założenia, skonstruował hipotetyczny sylogizm, mający za cel wykazanie absurdalności rozumowania swego przeciwnika: to, co stworzone ginie; aniołowie i dusze zostali stworzeni; zatem aniołowie i dusze giną. Oczywista fałszywość wniosku oznacza, że przynajmniej jedna z przesłanek jest błędna.

Dzięki tak skonstruowanemu sylogizmowi Metody wykazał, że nieprawdziwe jest założenie o śmiertelności wszystkiego, co stworzone. W swoim rozumowaniu, w którym posłużył się tym samym czasownikiem $\gamma^{\prime} \gamma \nu 0 \mu \alpha \iota$ i tym samym obrazem bezpośredniego zaangażowania (rąk) Boga, chciał dowieść podobieństwo stworzenia człowieka i aniołów ${ }^{20}$. Natomiast dzięki porównaniu statusu pierwszego człowieka z naturą duszy, chciał podkreślić zdolność ludzkiego ciała do nieśmiertelności, co kontestował Aglaofon.

W innym miejscu Metody sformułował następujący argument za istotową nieśmiertelnością człowieka:

„Dlaczego Adam po obleczeniu odzieniem ze skór, został wygnany z raju i dlaczego uniemożliwiono mu spożywanie z drzewa życia i życie, jeżeli byłoby całkiem niemożliwe, by żył wiecznie w swoim ciele? [...] A zatem ciało mogłoby żyć wiecznie i być nieśmiertelne, jeżeli nie zostałoby mu zakazane spożywanie z drzewa życia" ${ }^{21}$.

Ta wypowiedź jest szczególnie doniosła, gdyż wyjaśnia, w jakim sensie Metody mówił o istotowej nieśmiertelności człowieka, a więc także jego ciała. Była ona dla niego pierwotną dyspozycją, jakimś rodzajem zalążkowej nieśmiertelności, w którą Bóg wyposażył człowieka. Aby jednak ten potencjał mógł się w pełni rozwinąc i osiągnąć doskonałość, pierwszy człowiek miał w sposób wolny podjąć współpracę z Bogiem, realizując jego wskazania i spożywając owoce $\mathrm{z}$ drzewa życia. Proces doskonalenia człowieka został więc uzależniony od właściwego korzystania przez niego z wolności. Takie uwarunkowanie otwierało możliwość osłabienia czy wręcz jakiegoś głębokiego uszkodzenia tej pierwotnej zalążkowej nieśmiertelności, co faktycznie nastąpiło w wyniku grzechu nieposłuszeństwa.

Metody, przeciwstawiając się deprecjonującym wartość ciała poglądom Aglaofona, wysunął więc dosyć nietypowe rozumienie nieśmiertelności. W jego opinii nieśmiertelne stworzenie to takie, które nie zginie na wieki, co

${ }^{20}$ Por. tamże II $15,5$.

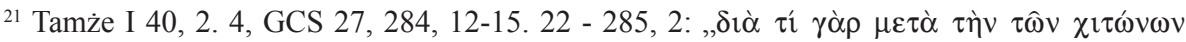

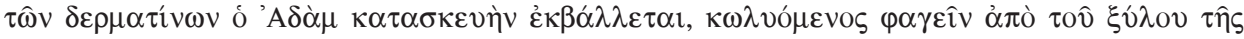

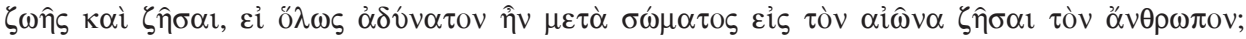

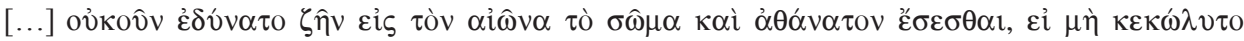

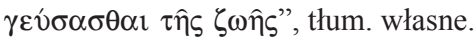


nie oznacza, że czasowo nie może ono podlegać śmierci. Jedynym absolutnie nieśmiertelnym, niezmiennym i niecierpiętliwym jest Bóg ${ }^{22}$. On jest samą Nieśmiertelnością. Wszelkie stworzenia, nawet te duchowe, podlegają zmianom. Metody wskazał na postać diabła, który został stworzony jako anioł światłości, a później dobrowolnie zbuntował się przeciw swemu Stwórcy. Przykład ten pozwolił mu na wykazanie różnicy pomiędzy nieśmiertelnością a niecierpiętliwością czy zmiennością (przeciw pierwszemu argumentowi Aglaofona), co wyraził w odważnym stwierdzeniu:

„Jedynie Ten, który stwarza może rozproszyć nawet to, co nieśmiertelne”23.

Metody bardzo świadomie użył tu czasownika $\lambda \hat{\omega} \omega$, a nie na przykład $\dot{\alpha} \pi \lambda^{\lambda} \lambda v \mu$. Wyraził w ten sposób opinię, że nie chodzi tu o całkowite zniszczenie czy unicestwienie, ale o jakiś rodzaj rozproszenia egzystencji. Uważał, że pomimo ogromnej deterioracji człowieka, wywołanej przez śmierć, jej panowanie jest czasowe, i jako takie nie przeczy istotowej nieśmiertelności człowieka. W innym miejscu Metody użył czasownika $\lambda \hat{\omega} \omega \mathrm{w}$ celu zobrazowania sposobu, w jaki Bóg oczyszcza człowieka przez śmierć, tak by następnie odrodzić go w zmartwychwstaniu. Chodzi mianowicie o przykład świątyni, na ścianach której wyrosły różne chwasty, a nawet drzewa. By ją gruntownie odnowić należy ją najpierw rozebrać, następnie wszystkie elementy składowe dokładnie oczyścić i dopiero wówczas zrekonstruować w pełnej krasie ${ }^{24}$.

Polemika z Aglaofonem zaznaczyła się też na polu interpretacji symbolu „odzienia ze skór” ( $\operatorname{Rdz} 3,21)$. Według Metodego odzienie to jest symbolem śmiertelności, a nie ludzkiego ciała ${ }^{25}$. Taka egzegeza umożliwiała mu przedstawienie śmierci jako rzeczywistości wtórnej w stosunku do pierwotnego stworzenia, czasowej i w pewnym sensie dobroczynnej. Rozpad ciała jest określonym ramami czasu jego oczyszczeniem i uwolnieniem z więzów pożądliwości i grzechu. Natomiast pełna realizacja istotowej nieśmiertelności człowieka, wraz z jego oczyszczonym z wszelkiej zmazy i uwolnionym od niedoskonałości ciałem, dokona się w zmartwychwstaniu.

${ }^{22}$ Por. tamże III 18, 4.

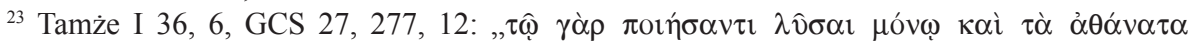
$\delta v v \alpha \tau o ́ v "$, tłum. własne. Metody prawie dosłownie oddał tu pogląd Atenagorasa (Libellus pro Christianis 24). Wyraźne są także podobieństwa z myślą Platona (Timaeus 41A-B, ed. Bury, s. 88, thum. Witwicki, t. 2, s. 690-691: „To, co ja zrodziłem nie ulega rozkładowi, bo ja tak chcę; [...] Skoroście się urodzili, nieśmiertelni nie jesteście, ani nierozkładalni w ogóle, ale nie ulegniecie rozkładowi, ani was śmierć nie spotka, bo was moja wola wiąże, a to jest więź jeszcze większa i potężniejsza niż te spójnie, które was związały przy powstawaniu").

${ }^{24}$ Por. Methodius, De resurrectione I 41, 1.

${ }^{25}$ Szerzej na ten temat, zob. J. Naumowicz, ,,Szaty ze skór”: kara czy ratunek dla człowieka? Patrystyczna interpretacja Rdz 3, 21, VoxP 30 (2010) 55, 463-475; M. Mejzner, Patrystyczna egzegeza ,odzienia ze skór” (Rdz 3,21), CT 83 (2013) fasc. 4, 157-173. 
5. Egzegeza Mdr 2, 23. Metody był świadomy, że jego nowatorska koncepcja musi zostać oparta na solidnym fundamencie biblijnym. Oprócz opisów stworzenia, zwrócił on szczególną uwagę na werset Mdr 2, 23: „dla niezniszczalności Bóg stworzył człowieka - uczynił go obrazem swej własnej wieczności”. Biskup Olimpu był pierwszym autorem chrześcijańskim, który wykorzystał ten werset w refleksji antropologicznej. W dziele $O$ zmartwychwstaniu przywołał go trzy razy ${ }^{26}$, łącząc zawsze $\mathrm{w}$ jakiś sposób z koncepcją pierwotnej nieśmiertelności, pomimo tego, że w Mdr 2, 23 termin $\alpha \dot{\alpha} \theta \alpha \nu \alpha \sigma i \alpha$ nie został użyty (występują za to terminy pokrewne: $\alpha \varphi \theta \alpha \rho \sigma i \alpha$ i ơï̇ıó $\tau \eta \varsigma)$.

Po raz pierwszy werset ten został wykorzystany w argumentacji skierowanej przeciw Aglaofonowi i jego pierwszej krytyce idei pierwotnej nieśmiertelności. Metody chciał uzasadnić, że śmierć nie przynależy do pierwotnego porządku stworzenia, ale że weszła na świat przez zawiść diabła. Człowiek, który na początku został pouczony, by w sposób wolny wybierał dobro, uległ jednak podszeptom kusiciela i dokonał aktu nieposłuszeństwa. Biskup Olimpu przywołał w tym miejscu nie tylko werset Mdr 2, 23, ale również Mdr 1, 13: „Bo śmierci Bóg nie uczynił i nie cieszy się ze zguby żyjących”, i Mdr 2, 24a: „A śmierć weszła na świat przez zawiść diabła”"27. Głównym celem tej argumentacji było wykazanie, że nieśmiertelność i śmierć nie są usytuowane na tych samych poziomach. Podczas, gdy ta pierwsza odpowiada pierwotnemu planowi Boga, ta druga jest konsekwencją działania wolnych stworzeń, i jako taka ma charakter czasowy i ograniczony.

Po raz drugi Metody użył wersetu Mdr 2, 23 w celu bezpośredniego potwierdzenia koncepcji istotowej nieśmiertelności człowieka:

„Wszystkie rodzaje istot nieśmiertelnych muszą być zbawione przez Boga.

Lecz także człowiek jest nieśmiertelny, ponieważ «Mądrość» mówi: «dla niezniszczalności Bóg stworzył człowieka - uczynił go obrazem swej własnej wieczności» (Mdr 2, 23). Ciało zatem nie ginie, ponieważ człowiek [jest złożony] z duszy i ciała"28.

Ten passus ukazuje w sposób wyjątkowo jasny logikę Metodego, który zdawał sobie sprawę, jak bardzo przesłanki antropologiczne rzutują na wnioski eschatologiczne. Jeżeli człowiek został stworzony dla nieśmiertelności jako ,jedność duszy i ciała połączonych w jednej formie piękna" ${ }^{29}$, to właśnie nieśmiertelność takiego bytu zostanie osiagnięta w zmartwychwstaniu. Jeżeli

${ }^{26}$ Por. Methodius, De resurrectione I 36, 2; I 50, 4; II 24, 4.

${ }^{27}$ Por. tamże I 36, 2.

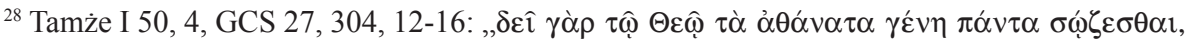

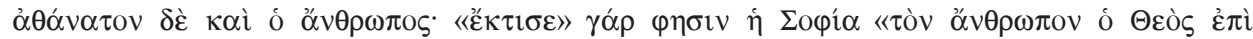

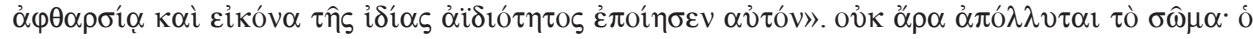

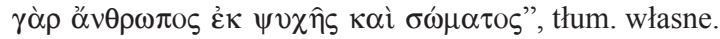

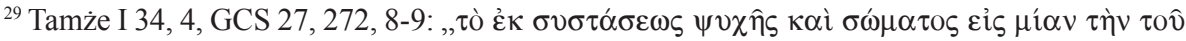

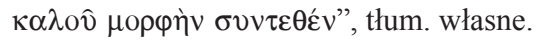


natomiast - jak utrzymywał Aglaofon - pierwotne stworzenie dotyczyłoby tylko duszy, a ciało byłoby zaledwie późniejszym, obciążającym dodatkiem, to oczekiwanie zmartwychwstania ciała nie tylko traciłoby sens, ale jego oczekiwanie byłoby wręcz czymś niedorzecznym.

Przy trzecim odwołaniu do Mdr 2, 23, Metody podjął analizę kategorii obrazu Bożego. Stwierdził, że skoro człowiek jest obrazem Bożej wieczności, to powinien być nieśmiertelny, nawet jeśli jego ciało zostało uczynione z pośledniej materii (to znaczy w jakimś sensie gorszej, niż materia duchowa, z której uczynione zostały ciała anielskie) $)^{30}$.

„Istotnie, z żadnej innej racji nie jesteśmy nieśmiertelni, jak z tylko tej, że jesteśmy obrazem Boga. Dlatego także i Logos zstąił, aby zamieszkać pośród nas i wcielił się w nasze ciało, aby odnowiwszy w sposób godny Boga ten obraz, który był zniszczony już od długiego czasu, wskrzesił go już niezniszczalnie" ${ }^{31}$.

Zacytowany passus ma szczególną doniosłość teologiczną, gdyż Metody połączył tu argumentację eschatologiczną nie tylko z protologiczną, ale także chrystologiczną. Znaczenie „nieśmiertelności principaliter” było dla niego tak ważne, że właściwie upatrywał w niej istotę podobieństwa do Boga ${ }^{32}$. Tę ludzką nieśmiertelność uważał jednak za rzeczywistość dynamiczną, to znaczy podlegającą zmianom. Jej status i stopień urzeczywistnienia zależy najpierw od Boga, a potem od wierności człowieka. Dlatego właśnie, pomimo zepsucia pierwotnego dzieła stworzenia, Bóg w Chrystusie odnowił swój nieśmiertelny obraz w człowieku.

$* * *$

Powszechność doświadczenia śmierci stawia pytania o jej przyczyny i naturę. Metody rozpatrywał problem śmierci w szerokim kontekście początków stworzenia. Z połączenia swoistej interpretacji pierwszych rozdziałów Księgi Rodzaju z pewnymi przesłankami filozoficznymi, wyprowadził koncepcję istotowej (pierwotnej) nieśmiertelności człowieka. Rozumiał przez nią nieśmiertelność zalążkową, stanowiącą obraz Nieśmiertelności Boga. Tylko ta ostatnia bowiem jest nieśmiertelnością absolutną, podczas gdy ta ludzka - jedynie „pochodna”. Jej konkretny, egzystencjalny status zależy od dostosowania wolnej woli człowieka do woli Bożej. Jeżeli następuje brak takiej

\footnotetext{
${ }^{30}$ Por. tamże II 24, 1-4.

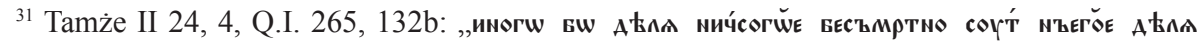

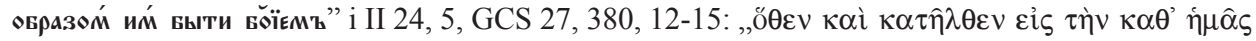

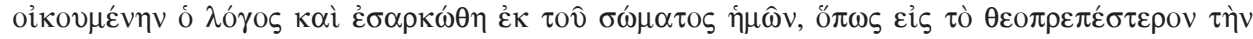

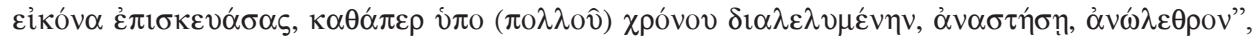
tłum. własne.

${ }^{32}$ Por. Bracht, Vollkommenheit und Vollendung, s. 28-30.
} 
koherencji, to stworzenie nieśmiertelne może czasowo doświadczyć śmierci, jako dramatycznej konsekwencji grzechu. Jednak śmierć nie jest dokładną paralelą nieśmiertelności, bo ta ostatnia przynależy do pierwotnego planu Boga, który ani się nie myli, ani nie zmienia swych postanowień ${ }^{33}$.

\section{THE CONCEPTION OF MAN'S IMMORTALITY \\ IN THE RESURRECTIONAL ARGUMENTATION OF METHODIUS OF OLYMPUS}

\section{(Summary)}

The foundation of the christian truth about the resurrection is the paschal event, ie the death and resurrection of Christ. However, the interpretation of this dogma is essentially linked to an anthropological vision, therefore the exegesis of biblical protology has a particular significance. At the start of the IV ${ }^{\text {th }}$ century, Methodius of Olympus undertook an interesting trial to clarify the status of the first man. Namely, departing from the traditional concept of medietas, which placed Adam in an indeterminate balance between immortality and death, he favoured the idea, which can be called "principaliter (essential or original) immortality". Thanks to this modification, the author of De resurrectione, gained an important point in resurrectional polemics. He thus presented death, not as an equivalent possibility linked with the original choice of man, but a consequence of his sin, certainly dramatic, but secondary to God's original plan. In this perspective, the resurrection of the body, and restoring it to immortality, appeared worthy and necessary, being the eschatic realisation of the Creator's design, his who cannot err.

Key words: Methodius of Olympus, resurrection, immortality, death, body.

Słowa kluczowe: Metody z Olimpu, zmartwychwstanie, nieśmiertelność, śmierć, ciało.

\footnotetext{
${ }^{33}$ Por. Methodius, De resurrectione I 39, 6.
} 
